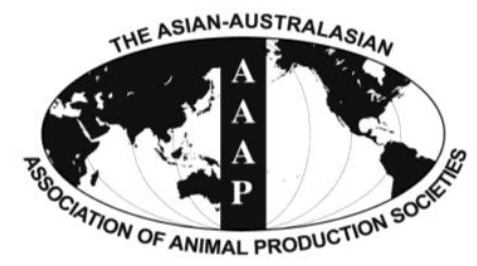

Asian-Aust. J. Anim. Sci.

Vol. 26, No. 2 : 266-274 February 2013

http://dx.doi.org/10.5713/ajas.2012.12511

www.ajas.info

pISSN 1011-2367 elSSN 1976-5517

\title{
Effect of Phytogenic Feed Additives in Soybean Meal on In vitro Swine Fermentation for Odor Reduction and Bacterial Community Comparison
}

\author{
M. J. Alam ${ }^{1,2}$, L. L. Mamuad ${ }^{1}$, S. H. Kim ${ }^{1}$, C. D. Jeong ${ }^{1}$, H. G. Sung ${ }^{3}$, S. B. Cho ${ }^{4}$, \\ C. O. Jeon ${ }^{5}$, K. Lee ${ }^{6}$ and Sang S. Lee ${ }^{1, *}$ \\ ${ }^{1}$ Ruminant Nutrition and Anaerobe Laboratory, Department of Animal Science and Technology, \\ Sunchon National University, Suncheon, Jeonnam 540-742 Korea
}

\begin{abstract}
The effect of different phytogenic feed additives on reducing odorous compounds in swine was investigated using in vitro fermentation and analyzed their microbial communities. Soybean meal (1\%) added with $0.1 \%$ different phytogenic feed additives (FA) were in vitro fermented using swine fecal slurries and anaerobically incubated for 12 and $24 \mathrm{~h}$. The phytogenic FAs used were red ginseng barn powder (Panax ginseng C. A. Meyer, FA1), persimmon leaf powder (Diospyros virginiana L., FA2), ginkgo leaf powder (Ginkgo biloba L., FA3), and oregano lippia seed oil extract (Lippia graveolens Kunth, OL, FA4). Total gas production, $\mathrm{pH}$, ammonianitrogen $\left(\mathrm{NH}_{3}-\mathrm{N}\right)$, hydrogen sulfide $\left(\mathrm{H}_{2} \mathrm{~S}\right)$, nitrite-nitrogen $\left(\mathrm{NO}_{2}^{-}-\mathrm{N}\right)$, nitrate-nitrogen $\left(\mathrm{NO}_{3}^{-}-\mathrm{N}\right)$, sulfate $\left(\mathrm{SO}_{4}^{--}\right)$, volatile fatty acids (VFA) and other metabolites concentration were determined. Microbial communities were also analyzed using 16S rRNA DGGE. Results showed that the $\mathrm{pH}$ values on all treatments increased as incubation time became longer except for FA4 where it decreased. Moreover, FA4 incubated for 12 and $24 \mathrm{~h}$ was not detected in $\mathrm{NH}_{3}-\mathrm{N}$ and $\mathrm{H}_{2} \mathrm{~S}$. Addition of FAs decreased ( $\mathrm{p}<0.05$ ) propionate production but increased $(\mathrm{p}<0.05)$ the total VFA production. Ten 16S rRNA DGGE bands were identified which ranged from 96 to $100 \%$ identity which were mostly isolated from the intestine. Similarity index showed three clearly different clusters: I (FA2 and FA3), II (Con and FA1), and III (FA4). Dominant bands which were identified closest to Eubacterium limosum (ATCC 8486T), Uncultured bacterium clone PF6641 and Streptococcus lutetiensis (CIP 106849T) were present only in the FA4 treatment group and were not found in other groups. FA4 had a different bacterial diversity compared to control and other treatments and thus explains having lowest odorous compounds. Addition of FA4 to an enriched protein feed source for growing swine may effectively reduce odorous compounds which are typically associated with swine production. (Key Words: Bacterial Community, In vitro Fermentation, Phytogenic Feed Additives, Swine Odorous Compounds)
\end{abstract}

\section{INTRODUCTION}

Currently, swine production's great problem is its foul odor. Feces odor is the result of incomplete anaerobic

\footnotetext{
* Corresponding Author: Sang Suk Lee. Tel: +82-61-750-3237, Fax: +82-61-750-3237, E-mail: rumen@ scnu.kr

2 Department of Animal Science, Sher-e-Bangla Agricultural University, Dhaka-1207, Bangladesh.

${ }^{3}$ Adbiotech Co. Ltd., Chun-Cheon City 200-880, Korea.

4 Animal Environment Division, National Institute of Animal Science, RDA, Suwon 441-706, Korea.

${ }^{5}$ Research Center for Biomolecules and Biosystems, Department of Life Science, Chung-Ang University, Seoul 156-756, Korea.

${ }^{6}$ Department of Animal Science, Ohio State University, 2029 Fyffe Road, Columbus, OH 43210, USA.

Submitted Sept. 18, 2012; Accepted Nov. 5, 2012; Revised Nov. 21, 2012
}

break-down of feed components, particularly peptides in the large intestine (Miner, 1977; Ritter, 1989). The result of this incomplete fermentation is a complex mixture of malodorous substances (Mackie et al., 1998). It is assumed that protein entering the large intestine can be a potential source of odor formation and microorganisms play a central role in the production of these odors (Ritter, 1989). Bacterial fermentation of undigested protein produces toxic substances such as ammonia-nitrogen, amines, VFA, and sulphur compounds (hydrogen sulfide, dimethyl disulfide) (Simpson et al., 1999). The compounds from the protein fermentation products have more unpleasant odor than the carbohydrate (CHO) fermentation products (Claesson et al., 1990). Based upon this information, it is logical to speculate that odors from swine production facilities can be diminished or lessened by reducing odor precursors 
originating from protein and its metabolites in the digestive tract of animals and in manure stores.

Microbial activities in the large intestine of the animal produce odorous compounds and provide precursors for odor formation in manure. Phytogenic feed additives (FA) are an extremely heterogenous group of feed additives originating from leaves, roots, tubers, or fruits of herbs, spices or other plants which are either available as solid, dried or ground form or as extracts or essential oils (Steiner, 2006). Windisch et al. (2008) concluded that FAs are claimed to exert antioxidative, antimicrobial, and growthpromoting effects in livestock, actions that are partially associated with enhanced feed consumption. Ritter (1989) added that they are one of the biochemical and chemical agents that can reduce odor from animal production facilities. The principle of using FA is to reduce odor formation and emission as well as to alter the microflora in the large intestine of animals and in manure, change the $\mathrm{pH}$ into less favorable for odor formation. Thus, altering the microflora and nutrient supply by adding FAs have the potential to change one or more groups of odorous compounds.

There is little information on phytogenic FA using SM as substrate and their effect on the large intestine microbiota. Thus, identifying the suitable FA and nutrient supply which influences beneficial microbial community is essential (Hume et al., 2006; Parker et al., 2007). Denaturing gradient gel electrophoresis-polymerase chain reaction (DGGEPCR) technique is one of DNA fingerprinting techniques which can be used to describe the microbial diversity of a variety of ecosystems in intestinal microbiota (Muyzer et al., 1993; Felske et al., 1998; Muyzer and Smalla, 1998; Konstantinov et al., 2003; Zhu et al., 2003). Studying the shifts in microbial populations could indicate which microbial species favored the gastrointestinal tract if a particular protein-based ingredient were included in a diet along with particular FA. Using protein as substrate may provide an important influence on the large intestine bacterial community since it is not digested by small intestine enzymes, but reaches the hindgut for fermentation by microorganisms. Therefore, this study evaluated the effect of different FAs using soybean meal as a substrate on reducing odorous compounds in swine by in vitro fermentation and analyzed their microbial communities using DGGE-PCR.

\section{MATERIALS AND METHODS}

\section{Experimental design, animals and diets}

The swine used in this study were selected from a commercial herd, and were the progeny of a Landracex Yorkshire sow and a Duroc sire. The experimental samples were collected from a total of 9 sixth month old castrated pigs with a live weight of $95 \pm 5 \mathrm{~kg}$. The experiment was conducted in the Ruminant Nutrition and Anaerobe Laboratory under the Department of Animal Science and Technology at Sunchon National University (SCNU), Republic of Korea. The experimental proposals and procedures for the care and treatment of the pigs were approved by the Animal Care Committee of SCNU. The animals were housed at the SCNU research farm which was well equipped with water, feed, and disposal systems, and individual pens $(12.7 \mathrm{~cm} \times 7.6 \mathrm{~cm})$ with fully slatted floors. The diets were fed to the pigs as mash ad libitum in the experimental period. The nutrient composition of the basal diet was in accordance with the suggestions of the nutrient requirements for swine from NRC (1998) are shown in Table 1.

Fresh pig fecal samples were collected directly from the rectum of the swine and transferred to a thermo flask at $39^{\circ} \mathrm{C}$ under vacuum condition. Collected feces were mixed with $10 \%(\mathrm{~W} / \mathrm{V})$ salt media under a constant flow of $\mathrm{CO}_{2}$ (Jensen et al., 1995; Wang et al., 2004). The homogenate was filtered using sterile cheese cloth and transferred 100 $\mathrm{ml}$ of filtrate to sterile serum bottles $(120 \mathrm{ml})$ containing one percent soybean meal (SM) and one tenth percent of

Table 1. Feed composition of basal diet fed to uncastrated growing-finishing swine ${ }^{1}$

\begin{tabular}{|c|c|}
\hline Ingredients/composition & Amount $(\mathrm{g} / \mathrm{kg})$ \\
\hline \multicolumn{2}{|l|}{ Ration formulation } \\
\hline Yellow corn & 451.5 \\
\hline Wheat & 250.0 \\
\hline Wheat bran & 40.0 \\
\hline Soybean meal & 160.0 \\
\hline Limestone & 7.8 \\
\hline Calcium phosphate & 11.0 \\
\hline Salt & 2.5 \\
\hline Vitamin-mineral premix ${ }^{2}$ & 5.5 \\
\hline Animal fat & 25.0 \\
\hline Molasses & 45.0 \\
\hline L-lysine & 1.7 \\
\hline \multicolumn{2}{|l|}{ Chemical composition } \\
\hline $\mathrm{ME}(\mathrm{MJ} / \mathrm{kg})$ & 13.66 \\
\hline Crude protein & 160.0 \\
\hline $\mathrm{Ca}$ & 5.0 \\
\hline Available P & 4.5 \\
\hline Lysine & 8.0 \\
\hline Methionine & 2.7 \\
\hline \multicolumn{2}{|c|}{$\begin{array}{l}{ }^{1} \text { Ace One, Seoul Feed Co., Ltd. \#678-1, Gojan-Dong, Namdong-Gu, } \\
\text { Incheon, South Korea } \\
{ }^{2} \text { Per kg vitamin-mineral premix provided the following nutrients: vitamin } \\
\text { A, } 6,000 \mathrm{IU} \text {; vitamin } \mathrm{D}_{3}, 800 \mathrm{IU} \text {; vitamin } \mathrm{E}, 20 \mathrm{IU} \text {; vitamin } \mathrm{K}_{3}, 2 \mathrm{mg} \text {; } \\
\text { thiamin, } 2 \mathrm{mg} \text {; riboflavin, } 4 \mathrm{mg} \text {; vitamin } \mathrm{B}_{6}, 2 \mathrm{mg} \text {; vitamin } \mathrm{B}_{12}, 1 \mathrm{mg} \text {; } \\
\text { pantothenic acid, } 11 \mathrm{mg} \text {; niacin, } 10 \mathrm{mg} \text {; biotin, } 0.02 \mathrm{mg} \text {; CuSO } \mathrm{Cu}_{4} \text { (copper } \\
\text { sulfate), } 21 \mathrm{mg} ; \mathrm{FeSO}_{4} \text { (ferrous sulfate), } 100 \mathrm{mg} \text {; } \mathrm{ZnSO}_{4} \text { (zinc sulfate), } \\
60 \mathrm{mg} ; \mathrm{MnSO}_{4} \text { (manganese sulfate), } 90 \mathrm{mg} \text {; CaIO } \text { (calcium iodate), } 1.0_{4} \text { mg; } \mathrm{Co}\left(\mathrm{NO}_{3}\right)_{2} \text { (cobalt nitrate), } 0.3 \mathrm{mg} \text {; } \mathrm{NaSe} \text { (sodium selenite), } 0.3 \mathrm{mg} \text {. }\end{array}$} \\
\hline
\end{tabular}


phytogenic FA anaerobically $\mathrm{O}_{2}$-free $\mathrm{CO}_{2}$. The bottles were then sealed with sterile butyl rubber stoppers that were kept in place with metal screw caps. The filled serum bottles were subsequently placed in a HB-201SF shaking incubator (HANBAEK Scientific Co., Korea) set at $50 \mathrm{rpm}$ and $37^{\circ} \mathrm{C}$ in anaerobic incubations for 12 and $24 \mathrm{~h}$.

The phytogenic FAs used were red ginseng barn powder (Panax ginseng C. A. Meyer, FA1), persimmon leaf powder (Diospyros virginiana L., FA2), ginkgo leaf powder (Ginkgo biloba L., FA3), and oregano lippia seed oil extract (Lippia graveolens Kunth, OL, FA4). All treatments and Con were replicated in three. Total gas production, $\mathrm{pH}$, $\mathrm{NH}_{3}-\mathrm{N}$, hydrogen sulfide $\left(\mathrm{H}_{2} \mathrm{~S}\right)$ and VFA and other metabolites were determined at 12 and $24 \mathrm{~h}$ while nitrite $\left(\mathrm{NO}_{2}\right)$, nitrate $\left(\mathrm{NO}_{3}\right)$, sulfate $\left(\mathrm{SO}_{4}\right)$ concentration and PCRDGGE at $24 \mathrm{~h}$ of incubation.

\section{Analysis of odorous compounds}

Total gas production (press and sensor machine (Laurel Electronics, Inc., Costa Mesa, CA, USA)), $\mathrm{H}_{2} \mathrm{~S}$ and $\mathrm{NH}_{3}-\mathrm{N}$ (VRAE Multi-Gas Monitor PGM-7840 (RAE Systems Inc., Sunnyvale, CA, USA)), pH (Pinnacle series M530p meter (Schott Instruments D-55122 Mainz, Germany)), and VFAs and other metabolites (high performance liquid chromatography (HPLC) (Agilent Technologies 1200 series, USA) according to the methods of Tabaru et al. (1988) and Han et al. (2005) were measured from each of the serum bottles at different.

\section{Analysis of indirect compounds}

Fermented samples (preserved) were centrifuged at $890 \times \mathrm{g}$ for $15 \mathrm{~min}$ at $4^{\circ} \mathrm{C}$ and the supernatants were then filtered through $0.2-\mu \mathrm{m}$ cellulose acetate filters. The filtered supernatants were then used for analysis of nitrite, nitrate and sulfate. The nitrite- $\mathrm{N}$ concentration was determined using a Griess reagent kit (G-7921, Molecular Probes (2003)) according to manufacturer's method. The developed nitrite standard and equation were $\mathrm{R}^{2}=0.9989$ and $\mathrm{y}=$ $0.1748 x+0.0051$, respectively. The absorbance of the nitrite was determined using the OD at $548 \mathrm{~nm}$ against reference with aforementioned equation. The nitrate concentration was measured based on the OD at $410 \mathrm{~nm}$ following the modified method described by (Jenkins and Medsker, 1964). The OD values were calculated from the equation developed from standard solution $y=0.005 x-0.0057\left(R^{2}=\right.$ 0.9973 ) and values were expressed as $\mathrm{mg} \mathrm{NO}_{3}-\mathrm{N} / \mathrm{L}$. For determination of the sulfate concentration, the modified turbidimetric method conducted according to the method described by (Kolmert et al., 2000) with absorbance at 420 $\mathrm{nm}$. For calculation, the OD values were fitted with an equation, $\mathrm{y}=0.0032 \mathrm{x}+0.0043$ and standard, $\mathrm{R}^{2}=0.9911$ to obtain an accurate sulfate concentrations.

\section{Microbiological analysis}

Fermented samples (preserved) were extracted using Wizard Genomic DNA Purification Kits (Promega, USA). 16S rDNA PCR amplification was performed using 27F and 1492R universal primers. DGGE was performed using a D-Code Universal Mutation Detection System (Bio-Rad, Hercules, CA, USA). To amplify the V3 region of the bacterial 16S rDNA amplicons, 341F-GC and 518R were used (Nübel et al., 1996). Amplicons of the V3 region of 16S rDNA were used for sequence-specific separation by DGGE according to the specifications of Muyzer and Smalla (1998). The DGGE gel was scanned at $400 \mathrm{dpi}$ and similarity indices were calculated for pairs of DGGE profiles. The number of DGGE bands and similarity indices were calculated from the densitometric curves of the scanned DGGE profiles with Molecular Analyst 1.12 software (Bio-Rad) using the Pearson product-moment correlation coefficient (Häne et al., 1993; Simpson et all, 1999) from the Central Microbiology Laboratory of SCNU in Korea.

A total of 10 purified dominant bands were sent to Macrogen, Seoul, Korea for sequencing. Results were compared to Gen-Bank database using the BLAST tool of the National Center for Biotechnology Information (NCBI) and EzTaxon.

\section{Statistical analysis}

Means of triplicates from treatments and control were analyzed by one-way analysis of variance (ANOVA) using the General Linear Models (GLM) procedures of the Statistical Analysis Systems Institute (SAS, 2002). The effects of the FAs on total gas, $\mathrm{pH}, \mathrm{NH}_{3}-\mathrm{N}, \mathrm{H}_{2} \mathrm{~S}, \mathrm{VFA}, \mathrm{NO}_{2}$, $\mathrm{NO}_{3}$, and $\mathrm{SO}_{4}$ concentrations were compared to the controls and significant differences between treatment means were examined using Duncan's multiple comparison tests. Variability in the data was expressed as pooled mean values \pm standard error (SE) and significance was declared at $\mathrm{p}<0.05$ for all variables measured.

\section{RESULTS AND DISCUSSION}

\section{Effect of FAs on odorous compounds after in vitro fermentation}

Predominant formation of malodorous substances occurs in the large intestine due to microbial degradation of several substrates (Jensen and Hansen, 2006). Total gas (TG) production, $\mathrm{pH}$, ammonia-nitrogen $\left(\mathrm{NH}_{3}-\mathrm{N}\right)$, hydrogen sulfide $\left(\mathrm{H}_{2} \mathrm{~S}\right)$, nitrite $\left(\mathrm{NO}_{2}{ }^{-}\right)$, nitrate $\left(\mathrm{NO}_{3}{ }^{-}\right)$and sulfate $\left(\mathrm{SO}_{4}^{--}\right)$concentrations of in vitro fermented swine fecal slurry added with soybean meal and different phytogenic feed additives was shown in Table 2. Results revealed that TG production increased as incubation time became longer. FA3 had the highest $(\mathrm{p}<0.05)$ total gas 
Table 2. Total gas production, $\mathrm{pH}$, ammonia-nitrogen $\left(\mathrm{NH}_{3}-\mathrm{N}\right)$, hydrogen sulfide $\left(\mathrm{H}_{2} \mathrm{~S}\right)$, nitrite-nitrogen $\left(\mathrm{NO}_{2}^{-}-\mathrm{N}\right)$, nitrate-nitrogen $\left(\mathrm{NO}_{3}^{-}-\mathrm{N}\right)$ and sulfate $\left(\mathrm{SO}_{4}^{--}\right)$concentrations of in vitro fermented swine fecal slurry added with soybean meal and different phytogenic feed additives

\begin{tabular}{|c|c|c|c|c|c|c|}
\hline \multirow{2}{*}{ Incubation time $(\mathrm{h})$} & \multicolumn{6}{|c|}{ Treatments } \\
\hline & Control & FA1 & FA2 & FA3 & FA4 & SEM \\
\hline \multicolumn{7}{|c|}{ Total gas production $(\mathrm{ml} / \mathrm{g})$} \\
\hline 12 & $60.33^{\mathrm{ab}}$ & $63.01^{\mathrm{a}}$ & $57.33^{\mathrm{b}}$ & $62.33^{\mathrm{a}}$ & $57.67^{\mathrm{b}}$ & 1.386 \\
\hline 24 & $86.33^{\mathrm{e}}$ & $101.67^{\mathrm{c}}$ & $107.00^{\mathrm{b}}$ & $112.30^{\mathrm{a}}$ & $94.00^{\mathrm{d}}$ & 0.954 \\
\hline \multicolumn{7}{|l|}{$\mathrm{pH}$ value } \\
\hline 12 & $5.85^{\mathrm{b}}$ & $5.78^{\mathrm{c}}$ & $5.79^{c}$ & $5.77^{\mathrm{cd}}$ & $5.92^{\mathrm{a}}$ & 0.004 \\
\hline 24 & $5.85^{\mathrm{b}}$ & $5.85^{\mathrm{b}}$ & $5.91^{\mathrm{a}}$ & $5.81^{\mathrm{bc}}$ & $5.8^{\mathrm{bc}}$ & 0.008 \\
\hline \multicolumn{7}{|l|}{$\mathrm{NH}_{3}-\mathrm{N}(\mathrm{mg} / \mathrm{L})$} \\
\hline 12 & $200.00^{\mathrm{a}}$ & $124.67^{\mathrm{b}}$ & $62.00^{\mathrm{c}}$ & $44.67^{\mathrm{d}}$ & ND & 2.608 \\
\hline 24 & 39.33 & ND & ND & ND & ND & 0.168 \\
\hline \multicolumn{7}{|l|}{$\mathrm{H}_{2} \mathrm{~S}(\mathrm{mg} / \mathrm{L})$} \\
\hline 12 & 286.33 & 292.00 & ND & ND & ND & 0.168 \\
\hline 24 & 25.60 & ND & ND & ND & ND & 0.144 \\
\hline $\mathrm{NO}_{2}-\mathrm{N}, \mathrm{mg} / \mathrm{L}, 24 \mathrm{~h}$ & $0.06^{\mathrm{d}}$ & $0.09^{\mathrm{cd}}$ & $0.17^{\mathrm{ab}}$ & $0.13^{\mathrm{bc}}$ & $0.22^{\mathrm{a}}$ & 0.014 \\
\hline $\mathrm{NO}_{3}-\mathrm{N}, \mathrm{mg} / \mathrm{L}, 24 \mathrm{~h}$ & $337.41^{\mathrm{b}}$ & $348.34^{\mathrm{b}}$ & $361.67^{\mathrm{b}}$ & $352.67^{\mathrm{b}}$ & $418.27^{\mathrm{a}}$ & 12.186 \\
\hline $\mathrm{SO}_{4^{--}}, \mathrm{mg} / \mathrm{L}, 24 \mathrm{~h}$ & $445.01^{\mathrm{b}}$ & $517.41^{\mathrm{a}}$ & $510.95^{\mathrm{ab}}$ & $516.05^{\mathrm{a}}$ & $547.62^{\mathrm{a}}$ & 16.342 \\
\hline
\end{tabular}

Means within a row with different superscripts differ significantly $(\mathrm{p}<0.05)$ by DMRT.

FA1 $=$ Red ginseng barn powder; FA2 = Persimmon leaf powder; FA3 = Ginkgo leaf powder; FA4 = Oregano lippia seed oil extract $(\mathrm{OL})$.

production among all treatments and control incubated at 12 and $24 \mathrm{~h}$. This agrees with Robinson et al. (1989) findings wherein TG production is directly proportional to incubation time due to increased fermentation over time. Also, TG was found higher compared to our previous results obtained wherein the FAs added but starch was used as substrate (Alam et al., 2012). Moreover, result was also partially similar to Patra et al. (2006) results in which total gas production as well as odorous compounds increased within the duration of incubation period. However, increase in gas production is not an indicator of odor intensity because it depends on what types of odorous compounds are produced.

The $\mathrm{pH}$ values on all treatments increased as incubation time became longer while FA4 decreased. The current result obtained on $\mathrm{pH}$ value was opposite of our previous research obtained in Alam et al. (2012). This is due to different substrate used during in vitro fermentation. Reduced $\mathrm{pH}$ of FA4 from 12 to $24 \mathrm{~h}$ incubation was supported by Risley et al. (1992) and Kempen (2001), stating that lowering the pH of urine and subsequent slurry can be beneficial for reducing odor and $\mathrm{NH}_{3}-\mathrm{N}$ emissions. Maintaining the proper acid-base balance and buffering capacity of the diet and the intestinal contents may influence the final $\mathrm{pH}$. In addition, Bailey et al. (2002) stated that anaerobic incubation with additive added fermenta caused significant time-dependent decreases in $\mathrm{pH}$ from 0 to $24 \mathrm{~h}$. This trend of lowering $\mathrm{pH}$ is probably beneficial when it comes to reducing odorous compounds.

$\mathrm{NH}_{3}-\mathrm{N}$ concentration of FA2 was lowest $(\mathrm{p}<0.05)$ after
$12 \mathrm{~h}$ of incubation followed by FA3, FA1 and control, respectively while FA4 was not detected. Moreover, only control was detected with $\mathrm{NH}_{3}-\mathrm{N}$ concentration after $24 \mathrm{~h}$ of incubation. Naidu et al. (2002) stated that a novel probiotic effectively reduced sulfur and $\mathrm{NH}_{3}-\mathrm{N}$ compounds in vitro. $\mathrm{NH}_{3}-\mathrm{N}$ gas concentration reduction might be due to the antimicrobial effect of the FA. Macfarlane and Macfarlane (2003) showed that $\mathrm{NH}_{3}-\mathrm{N}$ and odorous branched chain fatty acids are produced from the fermentation of amino acids. Killeen et al. (1998) reported that FAs contain subfractions which have partially antagonistic properties on intestinal urease activity and $\mathrm{NH}_{3}-\mathrm{N}$ formation under in vitro conditions. In addition, Duffy et al. (2001) confirmed the existence of active components in extracts which lowered or reduced intestinal urease activity and enzymes involved in the metabolic urea cycle.

$\mathrm{H}_{2} \mathrm{~S}$ concentration was not detected in FA2, FA3 and FA4 at 12 and $24 \mathrm{~h}$ of incubation. Meanwhile, FA1 $\mathrm{H}_{2} \mathrm{~S}$ concentration was only detected at $12 \mathrm{~h}$ but it was detected at 12 and $24 \mathrm{~h}$ incubation in control. FA2 to FA4 significantly reduced to undetectable amounts of $\mathrm{H}_{2} \mathrm{~S}$. Fakhoury et al. (2000) stated that $\mathrm{H}_{2} \mathrm{~S}$ had the highest correlation of malodorous sulphur compounds which may be reduced by adding selective FAs to the diet. Moreover, Le et al. (2005) reported that a change in $\mathrm{pH}$ may also change the release of other odorous compounds such as hydrogen sulfide. The decreased in $\mathrm{pH}$ of FA4 explains the reduced to undetectable amounts of $\mathrm{H}_{2} \mathrm{~S}$.

$\mathrm{NO}_{2}-\mathrm{N}$ concentration was better in FA supplemented 
groups than control while $\mathrm{NO}_{3}-\mathrm{N}$ concentration was better in FA4. After $24 \mathrm{~h}$ of incubation, $\mathrm{NO}_{2}-\mathrm{N}$ and $\mathrm{NO}_{3}-\mathrm{N}$ concentration was highest $(\mathrm{p}<0.05) \mathrm{FA} 4 . \mathrm{NH}_{3}-\mathrm{N}$ is nitrified by bacterial enzymes and converted to $\mathrm{NO}_{2}$ and $\mathrm{NO}_{3}$. Ward (1996) explained that oxidation of $\mathrm{NH}_{3}-\mathrm{N}$ to $\mathrm{NO}_{3}$ is called nitrification which is the result of actions of the nitrosifyers ( $\mathrm{NH}_{3}$-oxidizing, $\mathrm{NO}_{2}$ producing bacteria) and nitrifying bacteria $\left(\mathrm{NO}_{2}\right.$-oxidizing, $\mathrm{NO}_{3}$ producing bacteria). Bengtson (2010) also showed the $\mathrm{NH}_{3}-\mathrm{N}, \mathrm{NO}_{2}$, and $\mathrm{NO}_{3}$ correlation and their conversion through $\mathrm{N}$-cycle. This explains that the conversion of $\mathrm{NO}_{2}$ or $\mathrm{NO}_{3}$ from $\mathrm{NH}_{3}-\mathrm{N}$ is beneficial for odor reduction during incubation period. FA4 might be a good FA for reducing nitrogen compounds through conversion to $\mathrm{NO}_{2}$ and $\mathrm{NO}_{3}$.

Evaluation of $\mathrm{SO}_{4}$ production is an indirect method used to evaluate $\mathrm{H}_{2} \mathrm{~S}$. In the metabolic pathway, the conversion of $\mathrm{H}_{2} \mathrm{~S}$ to $\mathrm{SO}_{4}$ is referred to as chemolithotrophic oxidation of sulfur (Kelly, 1982) is favorable to odor reduction; therefore, higher $\mathrm{SO}_{4}$ production is better. $\mathrm{SO}_{4}$ concentration was highest $(\mathrm{p}<0.05)$ in FA4, FA1 and FA3 followed by FA2 and control, respectively. Hao et al. (1996) reported that sulfur-containing compounds are produced by bacteria through two processes: reduction of $\mathrm{SO}_{4}$ and metabolism of sulfur-containing amino acids. $\mathrm{SO}_{4}$ reduction proceeds via either assimilatory or dissimilatory pathways. In the first process, bacteria produce enough reduced sulfur for cell biosynthesis, while in the second process $\mathrm{SO}_{4}$ is utilized as a terminal electron acceptor and large quantities of sulfide are produced. It was observed in the present experiment that FA treatments were more effective in reducing $\mathrm{H}_{2} \mathrm{~S}$ to $\mathrm{SO}_{4}$ than control at $24 \mathrm{~h}$.

Gibson et al. (1988) stated that $\mathrm{SO}_{4}$-reducing bacteria (SRB) may play an important role in the terminal stages of fermentation in the colon and in particular, their ability to utilize hydrogen can prevent excessive amounts of this gas from accumulating in the colonic lumen. FA added in this experiment might help in the stimulation of those beneficial bacteria, such as sulfate-producing bacteria which reduces the sulfide. This effect might be due to FA's enhancement of beneficial microbes and anti-microbial action against undesirable microbes (Spoelstra, 1980). Based upon our findings, we confirmed that selected FA groups produced more $\mathrm{SO}_{4}$ than control. So, FA4 as well as the other FAs are suitable to reduce $\mathrm{H}_{2} \mathrm{~S}$ by converting it to $\mathrm{SO}_{4}$.

Jensen and Hansen (2006) and Le et al. (2005) explained that the predominant formation of malodorous substances occurs in the large intestine due to microbial degradation of several substrates or residual feed components. Substrate fermentation depends on microbial activity which may be modified by antimicrobial FAs. VFA and other metabolites production of in vitro fermented swine fecal slurry added with soybean meal and different phytogenic feed additives were shown on Table 3. Formate was only detected in $12 \mathrm{~h}$ FA4 in vitro fermenta. Lactate production was highest $(\mathrm{p}<0.05)$ in FA3 but propionate and butyrate were found highest $(\mathrm{p}<0.05)$ in control and FA2 after $12 \mathrm{~h}$ of incubation, respectively. After $24 \mathrm{~h}$ of incubation, control has the highest $(\mathrm{p}<0.05)$ in lactate and propionate production while FA3 has the highest $(\mathrm{p}<0.05)$ butyrate production. Total VFA production was found highest $(\mathrm{p}<0.05)$ in FA2 followed by FA3, FA4, FA1 and Con, respectively after $12 \mathrm{~h}$ incubation while after $24 \mathrm{~h}$ incubation, FA3 was found highest $(\mathrm{p}<0.05)$ followed by FA2, FA4, FA1 and Con, respectively. van Beers-Schreurs et al. (1998) explained that the quantity of VFA depends on the amount and composition of the substrate and on the type

Table 3. Volatile fatty acids (VFA) and other metabolites production of in vitro fermented swine fecal slurry added with soybean meal and different phytogenic feed additives

\begin{tabular}{|c|c|c|c|c|c|c|}
\hline \multirow{2}{*}{ VFA and other metabolites } & \multicolumn{6}{|c|}{ Treatments (mg/L) } \\
\hline & Control & FA1 & FA2 & FA3 & FA4 & SEM \\
\hline \multicolumn{7}{|l|}{$12 \mathrm{~h}$ fermentation } \\
\hline Acetate & ND & ND & ND & ND & ND & 0 \\
\hline Formate & ND & ND & ND & ND & 21.20 & 1.54 \\
\hline Lactate & $780.30^{\mathrm{b}}$ & $624.75^{b c}$ & $546.30^{c}$ & $1,910.00^{\mathrm{a}}$ & $372.90^{\mathrm{d}}$ & 121.30 \\
\hline Propionate & $561.10^{\mathrm{a}}$ & $375.25^{c}$ & $427.80^{\mathrm{b}}$ & $379.30^{c}$ & $381.50^{\mathrm{c}}$ & 52.32 \\
\hline Butyrate & $333.30^{\mathrm{d}}$ & $1,252.20^{\mathrm{c}}$ & $2,894.60^{\mathrm{a}}$ & $1,781.50^{\mathrm{b}}$ & $1,747.70^{\mathrm{b}}$ & 187.00 \\
\hline Total VFA & 894.40 & $1,627.50$ & $3,322.00$ & $2,161.00$ & $2,129.00$ & 0 \\
\hline \multicolumn{7}{|l|}{$24 \mathrm{~h}$ fermentation } \\
\hline Acetate & ND & ND & ND & ND & ND & 0 \\
\hline Formate & ND & ND & ND & ND & ND & 0 \\
\hline Lactate & $1,483.50^{\mathrm{a}}$ & $1,201.30^{\mathrm{ab}}$ & $298.90^{\mathrm{d}}$ & $511.80^{\mathrm{c}}$ & $519.40^{\mathrm{c}}$ & 108.50 \\
\hline Propionate & $1,391.40^{\mathrm{a}}$ & $1,103.90^{\mathrm{c}}$ & $474.30^{\mathrm{e}}$ & $819.50^{\mathrm{d}}$ & $1,272.60^{\mathrm{b}}$ & 135.70 \\
\hline Butyrate & $490.20^{\mathrm{e}}$ & $1,707.60^{\mathrm{cd}}$ & $3,936.60^{\mathrm{b}}$ & $4,043.70^{\mathrm{a}}$ & $2,134.60^{\mathrm{c}}$ & 221.80 \\
\hline Total VFA & $1,881.60$ & $2,811.50$ & $4,411.00$ & $4,863.00$ & $3,407.00$ & 0 \\
\hline
\end{tabular}

Means within a row with different superscripts differ significantly $(\mathrm{p}<0.05)$ by DMRT.

FA1 = Red ginseng barn powder; FA2 = Persimmon leaf powder; FA3 = Ginkgo leaf powder; FA4 = Oregano lippia seed oil extract $($ OL $)$. 


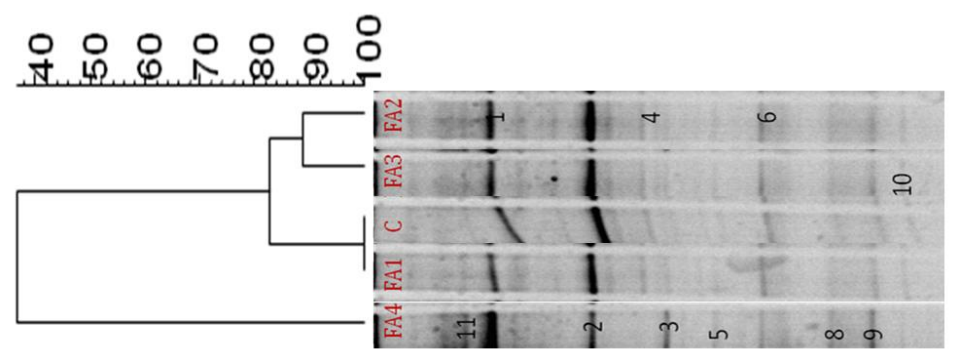

Figure 1. Negative image and similarity index of 16S rRNA DGGE amplified using total genomic DNA extracted from in vitro fermenta of swine fecal slurry added with different phytogenic feed additives. C: control; FA1, red ginseng barn powder; FA2, persimmon leaf powder; FA3, ginkgo leaf powder; FA4, oregano lippia seed oil extract (OL).

of microbes present in the cecum. Low VFA and other metabolites concentration indicates a low amount of substrate fermented and microbial activity in the cecum of pigs.

\section{Bacterial communities of in vitro fermenta added with different FAs}

Negative image and similarity index of $16 \mathrm{~S}$ rRNA DGGE amplified using total genomic DNA extracted from in vitro fermenta of swine fecal slurry added with different phytogenic feed additives was shown in Figure 1. These bands represented dominant species in the community that were enriched by SM and respective FAs. There were three clearly different clusters: I (FA2 and FA3), II (Con and FA1), and III (FA4). The similarity indices in profiles of clusters I, II, and III, were $88 \%, 100 \%$, and $36 \%$, respectively. FA4 had the lowest similarity among communities. In the previous research of Alam et al. (2012), the same FAs were added using starch as substrate but the bacterial community and similarity index were different from this research. This means that the substrate affects the bacterial community, similarity indices as well as identified dominant bands. FAs provide a subfraction for the bacteria that can utilize SM and affects their colonization of the large intestine as in vitro. The similarity index covered the range of different percentages for the clusters. The different ranges of the three clusters indicate that different FAs had an effect on the microbial communities during in vitro fermentation after $24 \mathrm{~h}$ of incubation. This supports the idea that different FAs create a strong selection pressure on the microbial community in vitro. Among the three clusters, cluster III (FA4) had the lowest similarity (36\%) which was evidence of a different microbial community. It has been shown that some FAs can beneficially affect the host by selectively stimulating the growth and or activity of one or a limited number of bacteria in the intestine or gut (Tannock, 1999). Overall, different clusters indicate that the bacterial communities were changed with the addition of FAs which might influence the intestinal bacterial communities involved in fermentation. Our results are consistent with the in vitro fermentation parameters and the concepts of Mao et al. (2008).

Identified dominant bands from 16S rRNA DGGE amplified using total genomic DNA extracted from in vitro fermenta of swine fecal slurry added with different feed additives was shown in Table 4. Identity ranges from 96 to $100 \%$ sequence similarity with 170 to $196 \mathrm{bp}$. Most of the identified bands were previously isolated from different digestive parts of different animals. Identified dominant bands were almost similar our previous result obtained (Alam et al., 2012). This is due to the same FAs added which obviously enhanced some bacterial species during

Table 4. Identified dominant bands from 16S rRNA DGGE amplified using total genomic DNA extracted from in vitro fermenta of swine fecal slurry added with different phytogenic feed additives

\begin{tabular}{clcc}
\hline Band no. & $\begin{array}{l}\text { Nearest relative } \\
\text { (GenBank accession no.) }\end{array}$ & Sequence similarity bp (\%) & Previous isolation \\
\hline 1 & Lactobacillus ultunensis (CCUG 48460T) & $195(100)$ & Chicken crop/human stomach \\
2 & Streptococcus macedonicus (ChF-II-str93) & $196(100)$ & Fossa cheese \\
3 & Eubacterium limosum (ATCC 8486T) & $172(99.42)$ & Human mouth \\
4 & Lactobacillus crispatus (DSM 20584T) & $195(100)$ & Chicken crop \\
5 & Uncultured bacterium clone PF6641 & $196(96)$ & Feces of pig \\
6 & Streptococcus alactolyticus (ATCC 43077T) & $196(100)$ & Chicken intestine \\
8 & Lactobacillus kitasatonis (JCM 1039T) & $181(97.24)$ & Gastro-intestinal tract of the pig \\
9 & Uncultured bacterium clone 20si13 & $170(100)$ & Rumen liquor of goat \\
10 & Rumen bacterium IVRI-RM-1008 & $196(100)$ & Fermented food \\
\hline 11 & Streptococcus lutetiensis (CIP 106849T) & $196(100)$ & \\
\hline
\end{tabular}


fermentation process. There were three dominant bands which were present only in the FA4 treatment group and were not found in other groups. They were identified closest to Eubacterium limosum (ATCC 8486T), Uncultured bacterium clone PF6641 and Streptococcus lutetiensis (CIP 106849T). The three distinct strains present in the FA4 fermented group probably modified the fermenta environment in some way, either utilizing or enhancing the odor reducing bacteria. FA4 had different bacterial diversity compared to control and other treatments and thus explains having lowest odorous compounds. However, the threshold for similarity to be considered as the same species is $97 \%$, according to Stackebrandt and Goebel (1994); therefore, it appears that the sequence of band no. 5 with similarity of $<97 \%$, likely represents some different, not yet cultured pig intestinal or fecal bacteria, that has not previously been identified. This is similar to the situation in the human intestine, where most species analyzed by DGGE and sequencing have not been previously identified (Zoetendal et al., 1998). FAs may provide a subfraction for bacteria that can utilize odor compounds, and these odor compoundutilizing bacteria may then accelerate the metabolism of the other intermediate products such as $\mathrm{NO}_{2}, \mathrm{NO}_{3}$ and $\mathrm{SO}_{4}$. The reported substantial reduction effect of certain FAs compared to others can be explained by the fact that it elicits detrimental effects on the microbial activities which release malodor from swine manure as well as function as masking agents (Varel and Miller, 2001). Currently, the precise mechanism of how the above additives reduce the odorous compounds is not well documented. A suggested explanation reported by $\mathrm{Kim}$ et al. (2008) is a transformation of the microbial species related to odor generation in the slurry. It may be due to changes in $\mathrm{pH}$, characteristics of the substrates, and microbial activities. FA4 of present experiment seems to function similarly. Moreover, herbs and spices are known to exert antimicrobial actions in vitro against important pathogens, including fungi (Özer et al., 2007). The antimicrobial mode of action is considered to arise mainly from the potential of the hydrophobic essential oils to intrude into the bacterial cell membrane, disintegrating membrane structures, and causing ion leakage. As such, FAs may also be beneficial to swine by reducing pathogens along with odor reduction.

\section{CONCLUSIONS}

OL generated a minimum of odorous compounds during in vitro fermentation. OL may be effectively used as a FA with protein-rich conditions in the large intestine to reduce the odor in growing swine. Moreover, selection of intestinal microbial species by a suitable FA in the in vitro conditions could provide a means to select or detect one or more bacterial species that could be appropriate for use as probiotics, either alone or in combination with animal diets. However, further research is needed using recommended FAs to determine whether these effects can also be detected in vivo at different ages factors along with $\mathrm{CHO}$ enrichment. Alternatively, real-time PCR using genus or strain-specific primers could be used to quantify the number of identified bacteria.

\section{ACKNOWLEDGEMENT}

This work was carried out with the support of "Cooperative Research Program for Agriculture Science and Technology Development (Project No. PJ0074512012)" Rural Development Administration, Republic of Korea.

\section{REFERENCES}

Alam, M. J., C. D. Jeong, L. L. Mamuad, H. G. Sung, D. W. Kim, S. B. Cho, K. Lee, C. O. Jeon and S. S. Lee. 2012. Bacterial community dynamics during swine in vitro fermentation using starch as a substrate with different feed additives for odor reduction. Asian-Aust. J. Anim. Sci. 25:690-700.

Bailey, S. R., A. Rycroft and J. Elliott. 2002. Production of amines in equine cecal contents in an in vitro model of carbohydrate overload. J. Anim. Sci. 80:2656-2662.

Bengtson, H. 2010. Easy to understand diagram of nutrient cycle. in The Importance of Nitrogen and the Nitrogen Cycle. L. Stonecypher, ed. Bright Hub, Inc. New York.

Claesson, R., M.-B. Edlund, S. Persson and J. Carlsson. 1990. Production of volatile sulfur compounds by various Fusobacterium species. Oral Microbiol. Immunol. 5:137-142.

Duffy, C. F., G. F. Killeen, C. D. Connolly and R. F. Power. 2001. Effects of dietary supplementation with Yucca schidigera Roezl ex Ortgies and its saponin and non-saponin fractions on rat metabolism. J. Agric. Food Chem. 49:3408-3413.

Fakhoury, K. J., A. J. Heber, P. Shao and J. Q. Ni. 2000. Correlation of odor detection thresholds with concentrations of hydrogen sulfide, ammonia and trace gases emitted from swine manure. Pages 1-13. American Society of Agricultural Engineers, St Joseph.

Felske, A., A. Wolterink, R. Van Lis and A. D. L. Akkermans. 1998. Phylogeny of the main bacterial 16S rRNA sequences in drentse a grassland soils (The Netherlands). Appl. Environ. Microbiol. 64:871-879.

Gibson, G. R., J. H. Cummings and G. T. Macfarlane. 1988. Competition for hydrogen between sulphate-reducing bacteria and methanogenic bacteria from the human large intestine. J. Appl. Microbiol. 65:241-247.

Han, S.-K., S.-H. Kim and H.-S. Shin. 2005. UASB treatment of wastewater with VFA and alcohol generated during hydrogen fermentation of food waste. Process Biochem. 40:2897-2905.

Häne, B. G., K. Jäger and H. G. Drexler. 1993. The Pearson product-moment correlation coefficient is better suited for identification of DNA fingerprint profiles than band matching algorithms. Electrophoresis 14:967-972.

Hao, O. J., J. M. Chen, L. Huang and R. L. Buglass. 1996. Sulfatereducing bacteria. Crit. Rev. Environ. Sci. Technol. 26:155-187. 
Hume, M. E., S. Clemente-Hernández and E. O. Oviedo-Rondón. 2006. Effects of feed additives and mixed Eimeria species infection on intestinal microbial ecology of broilers. Poult. Sci. 85:2106-2111.

Jenkins, D. and L. L. Medsker. 1964. Brucine method for the determination of nitrate in ocean, estuarine, and fresh waters. Anal. Chem. 36:610-612.

Jensen, M. T., R. P. Cox and B. B. Jensen. 1995. Microbial production of skatole in the hind gut of pigs given different diets and its relation to skatole deposition in backfat. Anim. Sci. 61:293-304.

Jensen, M. T. and L. L. Hansen. 2006. Feeding with chicory roots reduces the amount of odorous compounds in colon and rectal contents of pigs. Anim. Sci. 82:369-376.

Kelly, D. P. 1982. Biochemistry of the chemolithotrophic oxidation of inorganic sulphur. Phil. Trans. R. Soc. London. B, Biological Sciences 298:499-528.

Kempen, T. A. V. 2001. Dietary adipic acid reduces ammonia emission from swine excreta. J. Anim. Sci. 79:2412-2417.

Killeen, G. F., C. R. Connolly, G. A. Walsh, C. F. Duffy, D. R. Headon and R. F. Power. 1998. The effects of dietary supplementation with Yucca schidigera extract or fractions thereof on nitrogen metabolism and gastrointestinal fermentation processes in the rat. J. Sci. Food Agric. 76:91-99.

Kim, K.-Y., H.-J. Ko, H.-T. Kim, Y.-S. Kim, Y.-M. Roh, C.-M. Lee and C.-N. Kim. 2008. Odor reduction rate in the confinement pig building by spraying various additives. Bioresour. Technol. 99:8464-8469.

Kolmert, Å., P. Wikström and K. B. Hallberg. 2000. A fast and simple turbidimetric method for the determination of sulfate in sulfate-reducing bacterial cultures. J. Microbiol. Methods 41:179-184.

Konstantinov, S. R., W.-Y. Zhu, B. A. Williams, S. Tamminga, W. M. de Vos and A. D. L. Akkermans. 2003. Effect of fermentable carbohydrates on piglet faecal bacterial communities as revealed by denaturing gradient gel electrophoresis analysis of $16 \mathrm{~S}$ ribosomal DNA. FEMS Microbiol. Ecol. 43:225-235.

Le, P. D., A. J. Aarnink, N. W. Ogink, P. M. Becker and M. W. Verstegen. 2005. Odour from animal production facilities: its relationship to diet. Nutr. Res. Rev. 18:3-30.

Macfarlane, S. and G. T. Macfarlane. 2003. Regulation of shortchain fatty acid production. Proc. Nutr. Soc. 62:67-72.

Mackie, R. I., P. G. Stroot and V. H. Varel. 1998. Biochemical identification and biological origin of key odor components in livestock waste. J. Anim. Sci. 76:1331-1342.

Mao, S. Y., G. Zhang and W. Y. Zhu. 2008. Effect of disodium fumarate on ruminal metabolism and rumen bacterial communities as revealed by denaturing gradient gel electrophoresis analysis of $16 \mathrm{~S}$ ribosomal DNA. Anim. Feed Sci. Technol. 140:293-306.

Miner, J. R. 1977. Characterization of odors and other volatile emissions. Agric. Environ. 3:129-137.

Muyzer, G., E. C. de Waal and A. G. Uitterlinden. 1993. Profiling of complex microbial populations by denaturing gradient gel electrophoresis analysis of polymerase chain reactionamplified genes coding for $16 \mathrm{~S}$ rRNA. Appl. Environ. Microbiol. 59:695-700.

Muyzer, G. and K. Smalla. 1998. Application of denaturing gradient gel electrophoresis (DGGE) and temperature gradient gel electrophoresis (TGGE) in microbial ecology. Antonie van Leeuwenhoek 73:127-141.

Naidu, A. S., X. Xie, D. A. Leumer, S. Harrison, M. J. Burrill and E. A. Fonda. 2002. Reduction of sulfide, ammonia compounds, and adhesion properties of Lactobacillus casei strain KE99 in vitro. Curr. Microbiol. 44:196-205.

Nübel, U., B. Engelen, A. Felske, J. Snaidr, A. Wieshuber, R. I. Amann, W. Ludwig and H. Backhaus. 1996. Sequence heterogeneities of genes encoding 16S rRNAs in Paenibacillus polymyxa detected by temperature gradient gel electrophoresis. J. Bacteriol. 178:5636-5643.

Özer, H., M. Sökmen, M. Güllüce, A. Adigüzel, F. Şahin, A. Sökmen, H. Kiliç and Ö. Bariş. 2007. Chemical composition and antimicrobial and antioxidant activities of the essential oil and methanol extract of Hippomarathrum microcarpum (Bieb.) from Turkey. J. Agric. Food Chem. 55:937-942.

Parker, J., E. O. Oviedo-Rondón, B. A. Clack, S. ClementeHernández, J. Osborne, J. C. Remus, H. Kettunen, H. Mäkivuokko and E. M. Pierson. 2007. Enzymes as feed additive to aid in responses against Eimeria species in coccidia-vaccinated broilers fed corn-soybean meal diets with different proteinl levels. Poult. Sci. 86:643-653.

Patra, A. K., D. N. Kamra and N. Agarwal. 2006. Effect of spices on rumen fermentation, methanogenesis and protozoa counts in in vitro gas production test. Int. Congr. Ser. 1293:176-179.

Risley, C. R., E. T. Kornegay, M. D. Lindemann, C. M. Wood and W. N. Eigel. 1992. Effect of feeding organic acids on selected intestinal content measurements at varying times postweaning in pigs. J. Anim. Sci. 70:196-206.

Ritter, W. F. 1989. Odour control of livestock wastes: State-of-theart in North America. J. Agric. Eng. Res. 42:51-62.

Robinson, J. A., W. J. Smolenski, M. L. Ogilvie and J. P. Peters. 1989. In vitro total-gas, $\mathrm{CH}_{4}, \mathrm{H}_{2}$, volatile fatty acid, and lactate kinetics studies on luminal contents from the small intestine, cecum, and colon of the pig. Appl. Environ. Microbiol. 55:2460-2467.

SAS. 2002. SAS/STAT. Statistical analysis systems for Windows. Release 9.1. SAS Institute Inc., Cary, NC, USA

Simpson, J. M., V. J. McCracken, B. A. White, H. R. Gaskins and R. I. Mackie. 1999. Application of denaturant gradient gel electrophoresis for the analysis of the porcine gastrointestinal microbiota. J. Microbiol. Methods 36:167-179.

Spoelstra, S. F. 1980. Origin of objectionable odorous components in piggery wastes and the possibility of applying indicator components for studying odour development. Agric. Environ. 5:241-260.

Stackebrandt, E. and B. M. Goebel. 1994. Taxonomic Note: A place for DNA-DNA reassociation and 16S rRNA sequence analysis in the present species definition in bacteriology. Int. J. Syst. Bacteriol. 44:846-849.

Steiner, T. 2006. Managing gut health: Natural growth promoters as a key to animal performance. Nottingham University Press, Manor Farm, Main Street, Thrumpton Nottingham, NG11 OAX, United Kingdom.

Tabaru, H., E. Kadota, H. Yamada, N. Sasaki and A. Takeuchi. 1988. Determination of volatile fatty acids and lactic acid in bovine plasma and ruminal fluid by high performance liquid chromatography. Japanese J. Vet. Sci. 50:1124-1126. 
Tannock, G. W. 1999. Probiotics: a critical review. Prebiotics. Ward, B. B. 1996. Nitrification and ammonification in aquatic Horizon Scientific Press. systems. Life Support Biosph. Sci. 3:25-29.

van Beers-Schreurs, H. M. G., M. J. A. Nabuurs, L. Vellenga, H. J. Windisch, W., K. Schedle, C. Plitzner and A. Kroismayr. 2008. K.-v. d. Valk, T. Wensing and H. J. Breukink. 1998. Weaning and the weanling diet influence the villous height and crypt depth in the small intestine of pigs and alter the concentrations of short-chain fatty acids in the large intestine and blood. J. Nutr. 128:947-953.

Varel, V. H. and D. N. Miller. 2001. Plant-derived oils reduce pathogens and gaseous emissions from stored cattle waste. Appl. Environ. Microbiol. 67:1366-1370.

Wang, J. F., Y. H. Zhu, D. F. Li, Z. Wang and B. B. Jensen. 2004. In vitro fermentation of various fiber and starch sources by pig fecal inocula. J. Anim. Sci. 82:2615-2622. Use of phytogenic products as feed additives for swine and poultry. J. Anim. Sci. 86(14 suppl):E140-E148.

Zhu, W.-Y., B. A. Williams, S. R. Konstantinov, S. Tamminga, W. M. De Vos and A. D. L. Akkermans. 2003. Analysis of $16 \mathrm{~S}$ rDNA reveals bacterial shift during in vitro fermentation of fermentable carbohydrate using piglet faeces as inoculum. Anaerobe 9:175-180.

Zoetendal, E. G., A. D. L. Akkermans and W. M. De Vos. 1998. Temperature gradient gel electrophoresis analysis of 16S rRNA from human fecal samples reveals stable and host-specific communities of active bacteria. Appl. Environ. Microbiol. 64:3854-3859. 